\title{
SOME PROBLEMS IN THE HISTORY OF HAEMOGLOBINOMETRY (1878-1931)
}

by

\author{
A. D. FARR*
}

\section{SUMMARY}

THE COLORIMETRIC estimation of haemoglobin concentration by reference to a standard of diluted blood was introduced by Gowers in 1878 and, after modification by Haldane in 1901, was widely used until the 1960s. Haldane's "normal" standard was determined by measurement of a very small group of men in Belfast and subsequent work indicated apparent differences between this and the normal level in Britain thirty years later, and also differences between British and American "normal" levels. These differences are discussed and some possible explanations suggested to account for them.

\section{INTRODUCTION}

At the beginning of the present century the practice of haematology for clinical purposes was effectìvely restricted to total and differential red cell counts and to simple measurements of coagulation. Haemoglobin concentration was rarely estimated, and measurement of oxygen capacity was a research procedure outside the scope of clinical medicine. Wright was reported as saying that: "In hospitals at the present time, the chief, and in many hospitals the only, method of blood examination which was in use was the haemocytometric method,"1 while Lorrain Smith complained that: "The methods in ordinary use for examining the blood of patients suffering from anaemia fail to give any information whatever regarding the total quantity of blood in the circulation, or the total amount of haemoglobin which it contains."2

\section{COLORIMETRIC HAEMOGLOBINOMETRY}

A colorimetric method for the estimation of haemoglobin was introduced almost a century ago by Gowers, ${ }^{3}$ who devised an apparatus (Fig. 1) ${ }^{4}$ in which $20 \mathrm{~mm}^{3}$ of blood were dispensed into a few drops of distilled water in a glass tube, which was graduated " 100 degrees = two cubic centimetres". Distilled water was then added drop by drop "until the tint of the diluted blood is the same as that of the standard."

*A. D. Farr, B.A., Ph.D., F.I.M.L.S., “Rosslynlee”, 296 N. Deeside Road, Cults, Aberdeen AB1 9SB.

${ }^{1}$ A. Wright, in 'A discussion on the blood in disease', Trans. path. Soc. Lond., 1900, 51: 298.

2 J. L. Smith, ibid., p. 311.

W. R. Gowers, 'An apparatus for the clinical estimation of haemoglobin', Trans. clin. Soc. Lond., 1879, 12: 64-67. The paper was originally read before the society on 13 December 1878.

' Ibid., p. 66. 


\section{A. D. Farr}

Previous colorimetric methods had generally utilized a single dilution of blood and a series of artificial standards-mostly coloured glass or paper. Gowers was the first to use a single standard and varying dilutions of the blood under test. Diluted blood is unstable, however, and Gowers was obliged to use a tube containing glycerine jelly, coloured with "a mixture of carmine and picrocarminate of ammonia"-a mixture which, he claimed, "not only resembles diluted blood in its tint, but gives ... nearly the same absorption-bands in the spectrum."5 The artificial standard was made to resemble the colour of a 1 in 100 dilution of "normal" blood in distilled water so that, in the test, "the degrees of dilution employed to obtain the same tint represent the percentage proportion of the haemoglobin to that of normal blood."6

With the advantage of hindsight it is possible to see many flaws in Gowers' technique, but the most important of these is that "normal blood" is not a homogenous substance. Until 1900 no work was published which indicated either the range of normal haemoglobin levels in the population, or the correlation between these and the oxygen-carrying capacity of the blood. A further important flaw in Gowers' standard was that the tinted glycerine jelly tended to darken with time, so that standards were not permanent.

An important modification to Gowers' method was introduced by Haldane, who took advantage of the relative stability of carboxyhaemoglobin. ${ }^{7}$ Haldane used as his standard "a dilute solution of blood of known oxygen capacity, saturated with coal-gas. This solution is sealed up in a narrow test-tube after all the contained air has been displaced by coal-gas, and when thus completely sealed is permanent". ${ }^{8}$ In order to achieve a comparable colour in the test, Haldane followed a similar procedure to that of Gowers, ${ }^{9}$ but the solution of blood in water was "shaken with coal-gas, to saturation of the haemoglobin with carbonic oxide, before the final additions of water."10 This technique measured oxy-, carboxy-, and reduced haemoglobin, but not sulph- or met-haemoglobin.

The sale of Haldane haemoglobinometers (Fig. 2) ${ }^{11}$ in Britain only ceased in about 1963.

\section{NORMAL HAEMOGLOBIN LEVELS}

The definition of " 100 per cent haemoglobin", which permitted haemoglobin levels to be reported as a percentage of "normal", was established in 1900-01. Haldane and Smith ${ }^{12}$ performed a series of experiments upon fourteen men (mostly medical students and practitioners working in the Pathological Laboratory of Queen's College, Belfast) in which they showed (inter alia) that oxygen capacity averaged $18.5 \mathrm{~cm}^{3}$ per $100 \mathrm{~cm}^{3}$ of blood. Further work by $\mathrm{Smith}^{13}$ on six female medical

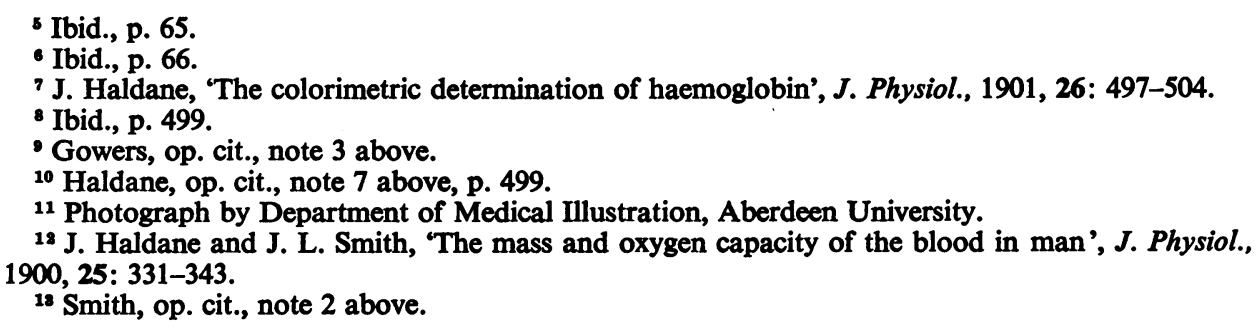




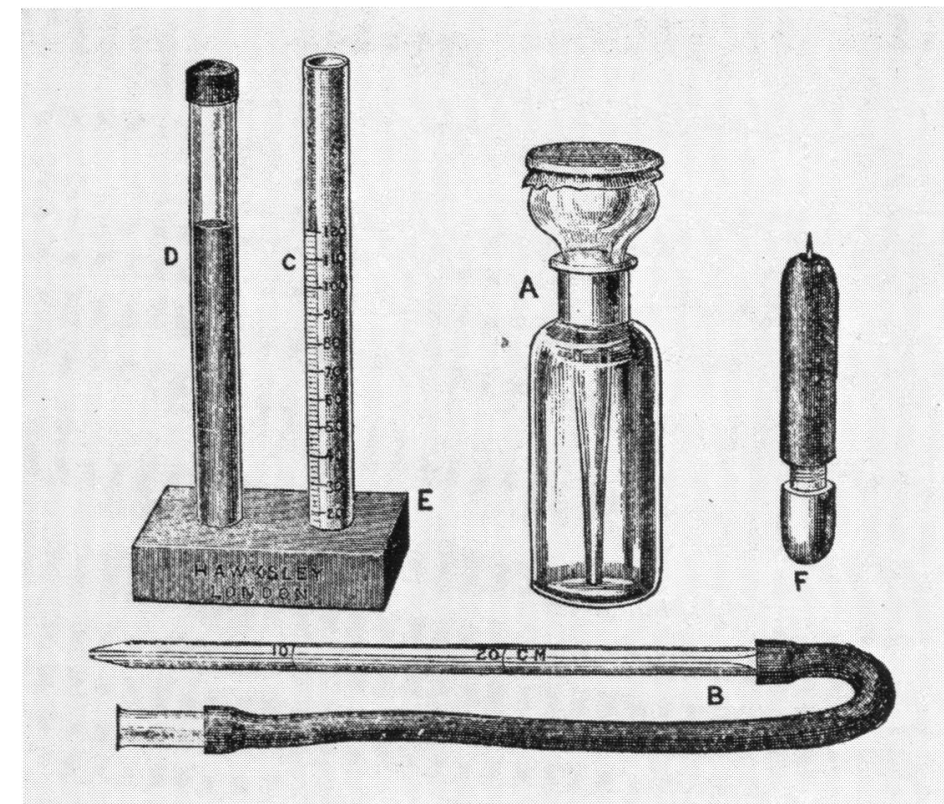

Figure 1.

Gowers' (1878) haemoglobin apparatus. (Trans. clin. Soc. Lond., 1879, 12: p. 65).

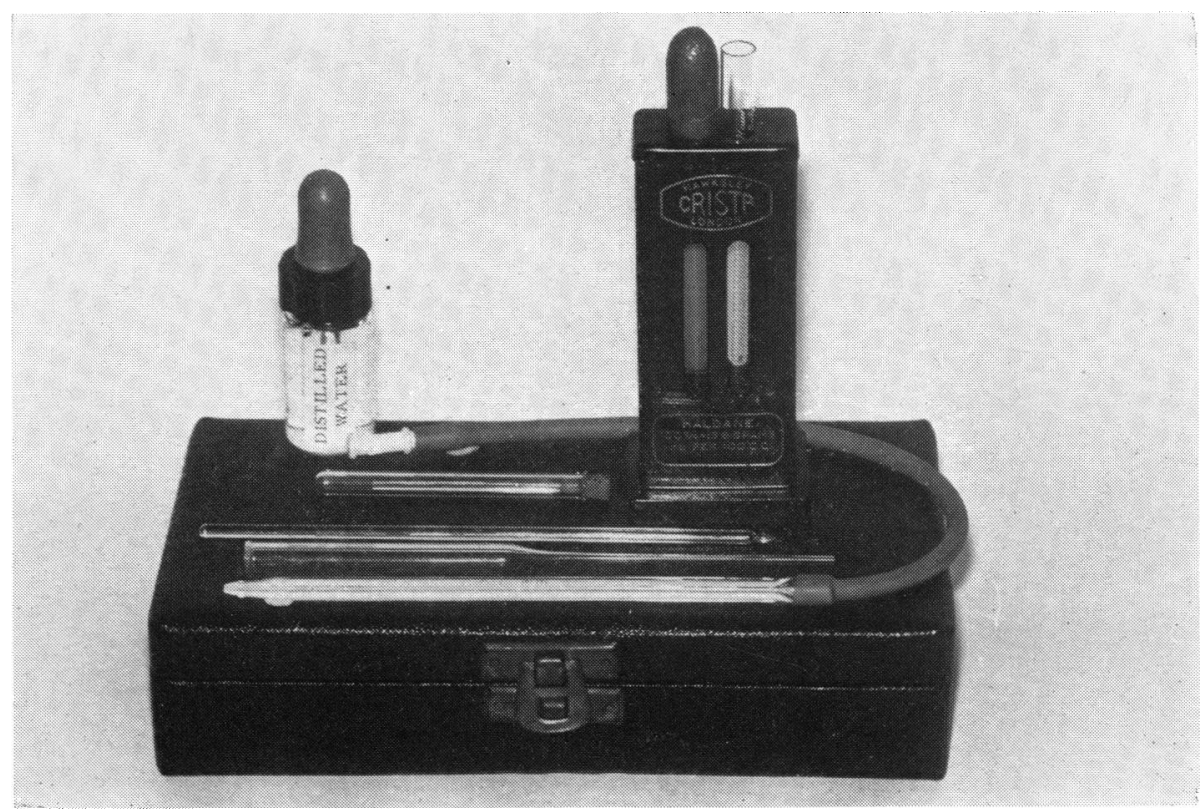

Figure 2.

Haldane's haemoglobinometer with carboxyhaemoglobin standard, $100 \%=13.8 \mathrm{~g} / \mathrm{dl}$. (Department of Medical Illustration, University of Aberdeen.) 


\section{Some problems in the history of haemoglobinometry (1878-1931)}

students and by Haldane ${ }^{14}$ upon twelve men and twelve women confirmed this figure and also established a "normal" oxygen capacity of $16.5 \mathrm{~cm}^{3}$ per $100 \mathrm{~cm}^{3}$ of blood for women.

A correlation between oxygen-carrying capacity and haemoglobin concentration had been established six years earlier by Hüfner, ${ }^{15}$ who had demonstrated that $1 \mathrm{~g}$ haemoglobin combined with $1.34 \mathrm{~cm}^{3}$ oxygen. From this it is possible to determine that an oxygen-carrying capacity of $18.5 \mathrm{~cm}^{3}$ per $100 \mathrm{~cm}^{3}$ of blood-taken as 100 per cent by both Haldane and Smith-was equivalent to $13.8 \mathrm{~g} / \mathrm{dl}$ of haemoglobin, and this figure was for many years accepted as the "normal" haemoglobin level in adults.

The work of Haldane and Smith in 1900-01 which established the "normal" haemoglobin level was performed upon no more than twenty-six men and twelve women, all of a similar social class and all from Belfast. That such a limited survey should have been used to establish a normal level for adults in the whole country may appear surprising - but that the "normal" thus established remained unquestioned for the ensuing thirty years is, perhaps, more so. That this did happen was clearly indicated by Price-Jones in 1931, who wrote: "It is customary in England to say that the blood of a healthy man has 100 per cent haemoglobin, corresponding to an oxygen capacity of 18.5 c.c. per 100 c.c. of blood; that the blood of a healthy woman has 90 per cent haemoglobin or 16.6 c.c. of oxygen per 100 c.c. of blood. These figures were established more than thirty years ago by Haldane and Lorrain Smith (1900) and Haldane (1901)."16

Price-Jones noted "a rather general impression that normal healthy males average more than 100 per cent" on Haldane's scale, and especially that American observers reported figures considerably higher. He wondered if "the healthy amount of haemoglobin has altered with the changed circumstances of modern life."17 In pursuit of this problem Price-Jones examined 100 healthy men and 100 healthy women in London. As with the original series of Haldane and Smith, the subjects were from hospital staff members, the men being students and members of the laboratory staff, average age twenty-seven, and the women being students and hospital nurses, average age twenty-four years. Price-Jones "regarded a person as healthy who said he was well and was doing his work properly; in the women no account was taken of menstrual loss."18

From his results Price-Jones concluded that the mean haemoglobin level for men was 105.4 per cent and for women 98.3 per cent. The corresponding oxygen capacity values, and haemoglobin levels in $\mathrm{g} / \mathrm{dl}$, are given in Table 1.

Price-Jones' results were, if anything, still on the low side, as was shown by his comparison of these with other-mainly American-studies which were performed between 1926 and $1930 .{ }^{19}$ Some of these results are summarized in Table 2.

\footnotetext{
14 Haldane, op. cit., note 7 above.

15 G. Hüfner, 'Neue Versuche zue Bestimmung der Sauerstoffcapacität der Blutfarbstoffs', Arch. Anat. Physiol., 1894, 130-176.

16 C. Price-Jones, 'The concentration of haemoglobin in normal human blood', J. Path. Bact., 1931, 34: 779-787, see p. 779.

17 Ibid.

18 Ibid., p. 780.

10 Ibid., p. 782.
} 


\section{A. D. Farr}

TABLB 1

Normal haemoglobin levels, derived from the figures of Price-Jones (1931) 10

\begin{tabular}{|l|ccc|c|ccc|}
\hline \multicolumn{3}{|c}{$\begin{array}{c}\text { Per cent. Hb on } \\
\text { the Haldane scale }\end{array}$} & $\begin{array}{c}\text { Per cent } \\
\text { oxygen } \\
\text { capacity }\end{array}$ & \multicolumn{3}{c|}{$\begin{array}{c}\text { Hb in } \\
\text { g/dl }\end{array}$} \\
\hline \multirow{3}{*}{ Men } & Minimum & Mean & Maximum & Mean & Minimum & Mean & Maximum \\
Women & 96 & 105.4 & 116 & 19.5 & 12.9 & 14.5 & 15.5 \\
& 90 & 98.3 & 110 & 18.1 & 12.1 & 13.6 & 14.7 \\
\hline
\end{tabular}

TABLE 2

Ranges of haemoglobin values reported by various workers, 1900-1931

\begin{tabular}{|c|c|c|c|c|c|c|c|}
\hline Observer & Country & Sample & $\begin{array}{r}\mathrm{Pe} \\
\text { the } \\
\text { Minimun }\end{array}$ & $\begin{array}{l}\text { cent } \mathbf{H} \\
\text { Ialdane } \\
\text { Mean }\end{array}$ & $\begin{array}{l}\text { on } \\
\text { cale } \\
\text { laximum }\end{array}$ & $\begin{array}{c}\text { Per cent } \\
\mathrm{O}_{2} \text { capacity } \\
\text { Mean }\end{array}$ & $\begin{array}{l}\mathrm{Hb} \text { in } \\
\mathrm{g} / \mathrm{dl} \\
\text { Mean }\end{array}$ \\
\hline $\begin{array}{l}\text { Haldane and Smith } \\
(1900-01)^{12,12,14}\end{array}$ & Ireland & $\begin{array}{l}26 \text { men } \\
18 \text { women }\end{array}$ & $\begin{array}{l}86 \\
87\end{array}$ & $\begin{array}{l}100 \\
90.4\end{array}$ & $\begin{array}{r}113 \\
98\end{array}$ & $\begin{array}{l}18.5 \\
16.7\end{array}$ & $\begin{array}{l}13.8 \\
12.5\end{array}$ \\
\hline $\begin{array}{l}\text { Price-Jones } \\
(1931)^{16}\end{array}$ & England & $\begin{array}{l}100 \text { men } \\
100 \text { women }\end{array}$ & $\begin{array}{l}96 \\
90\end{array}$ & $\begin{array}{r}105.4 \\
98.3\end{array}$ & $\begin{array}{l}116 \\
110\end{array}$ & $\begin{array}{l}19.5 \\
18.1\end{array}$ & $\begin{array}{l}14.5 \\
13.6\end{array}$ \\
\hline $\begin{array}{l}\text { Osgood and Haskins } \\
(1926-27)^{20}\end{array}$ & U.S.A. & $\begin{array}{l}137 \text { men } \\
100 \text { women }\end{array}$ & $\begin{array}{l}97 \\
79\end{array}$ & $\begin{array}{r}114.2 \\
99.5\end{array}$ & $\begin{array}{l}137 \\
119\end{array}$ & $\begin{array}{l}21.1 \\
18.3\end{array}$ & $\begin{array}{l}15.8 \\
13.7\end{array}$ \\
\hline $\begin{array}{l}\text { Wintrobe and Miller } \\
(1929-30)^{22}\end{array}$ & U.S.A. & $\begin{array}{l}100 \text { men } \\
50 \text { women }\end{array}$ & $\begin{array}{l}97 \\
85\end{array}$ & $\begin{array}{r}114.9 \\
99.7\end{array}$ & $\begin{array}{l}133 \\
115\end{array}$ & $\begin{array}{l}21.3 \\
18.4\end{array}$ & $\begin{array}{l}15.9 \\
13.8\end{array}$ \\
\hline Haden (1923) ${ }^{28}$ & U.S.A. & 40 men & 100 & 112.2 & 124 & 20.8 & 15.5 \\
\hline
\end{tabular}

It was clear from the increasing number of healthy individuals now being tested that Haldane's original "normal" standard of 100 per cent $=13.8 \mathrm{~g} / \mathrm{dl}$ of haemoglobin was no longer valid. Osgood and Haskins, referring to their own (American) findings, in which the mean normal figures were $14.7 \mathrm{~g} / \mathrm{dl}$ for men and $14.3 \mathrm{~g} / \mathrm{dl}$ for women, ${ }^{20}$ recommended that "These are the figures that should be taken as 100 per cent haemoglobin," ${ }^{21}$ while Wintrobe and Miller $^{22}$ recommended $14.3 \mathrm{~g} / \mathrm{dl}$ as a

${ }^{20}$ E. E. Osgood and H. D. Haskins, 'Relation between cell count, cell volume, and hemoglobin content of venous blood of normal young women', Arch. intern. Med., 1927, 39: 643-655. E. E. Osgood, 'Hemoglobin, color index, saturation index and volume index standards', ibid., 1926, 37: 685-706.

21 Osgood and Haskins, op. cit., note 20 above, p. 655.

"2 M. M. Wintrobe and M. W. Miller, 'Normal blood determinations in the south', Arch. intern. Med., 1929, 43: 96-113. M. M. Wintrobe, 'Blood of normal young women residing in a subtropical climate', ibid., 1930, 45: 287-301.

${ }^{23} \mathrm{R}$. L. Haden, 'Accurate criteria for differentiating anemias', Arch. intern. Med., 1923, 31 : 766-780. 


\section{Some problems in the history of haemoglobinometry (1878-1931)}

universal standard 100 per cent. ${ }^{24}$ Not surprisingly, the result of these-and similarconflicting claims as to what was "normal" was that varying figures were adopted, and 100 per cent standard tubes for Haldane's method were marketed (inter alia) at $13.8,14.6$, and $14.8 \mathrm{~g} / \mathrm{dl}$. It is interesting to note that as late as 1971 one clinician known to the present author was still insisting upon haemoglobin levels being estimated with a Haldane apparatus which utilized the original $13.8 \mathrm{~g} / \mathrm{dl}$ standard first established in 1900 .

In an attempt to explain the higher "normal" haemoglobin figures reported from America, Price-Jones visited Boston and confirmed that in America "healthy people seem really to have more haemoglobin in their blood than the same class of person in London." ${ }^{25}$ This difference was not easy to explain, for the tests had been performed in London and Boston upon groups of approximately equal social class and age, both residing nearly at sea level, so that Price-Jones could feel that "neither altitude, age nor standard of living can be regarded as factors in the question."26 The explanation offered for the higher American oxygen capacities was ingenious, however, and is worth quoting at length.

Price-Jones was "able to say that only comparatively few of the 100 men in my series possessed a motor car, whereas all the 20 men I examined in Boston had cars, and apparently used them a good deal. The number of motor cars in use in the United States is obviously far larger than in this country, and moreover the cars are usually closed, touring cars are rarely seen. The reality of carbon monoxide poisoning from motor cars has been fully established ... and I suggest that the motoring habit tends to cause a slow chronic poisoning by which the oxygen pressure is constantly being slightly reduced and that the bone marrow compensates for the useless carboxyhaemoglobin by making more red cells and haemoglobin and producing a relative polycythaemia."2?

It is possible that Price-Jones over-simplified the situation by dismissing the possibility that standards of living represented a factor in the transatlantic differences in haemoglobin levels. Although his subjects were from roughly the same social stratum in each country, there was no evidence that standards of living were the same for that stratum in each of the two countries, or that medical students and hospital staff represented the same proportion of the respective total populations-and therefore were equally typical of the "normal" healthy indigenous populations of Britain and America.

\section{RELIABILITY OF STANDARDS}

One further possibility remained to explain the different normal ranges found in Britain and America. Whereas in Britain, Haldane, Smith, and Price-Jones had all based their estimations of haemoglobin concentration upon standards calibrated by the ferricyanide method of measuring oxygen capacity, first described by Haldane, ${ }^{28}$

s Wintrobe and Miller, op. cit., note 22 above, p. 113.

2s Price-Jones, op. cit., note 16 above, p. 783.

26 Ibid.

27 Ibid., pp. 783-784.

28 J. Haldane, 'The ferricyanide method of determining the oxygen capacity of blood', J. Physiol., 1900, 25: 295-302. 
the American observers referred to in Table 2 had used standards based upon oxygen capacity determined by the method of van Slyke and Stadie, ${ }^{29}$ who claimed that Haldane's method gave results only 95.3 per cent as high as their own. ${ }^{30}$

In order to investigate this variable, Price-Jones had the oxygen capacity of twenty healthy male volunteers from Harvard University Medical School estimated in parallel by both Haldane's and van Slyke's methods. ${ }^{31}$ The results (summarized in Table 3) showed that while van Slyke and Stadie's method did, indeed, give higher results than Haldane's, the difference was small $\left(0.47 \mathrm{~cm}^{8}\right.$ per cent: equivalent to 2.6 per cent, or $0.36 \mathrm{~g} / \mathrm{dl}$, on Haldane's scale) and it was only apparent in eighteen of the twenty subjects tested.

TABLE 3

Oxygen capacity and equivalent haemoglobin concentrations estimated by different methods. (All figures are means, derived from the mean of two estimations on each of twenty subjects.) ${ }^{10}$

\begin{tabular}{|lcc|cc|}
\hline \multicolumn{3}{|c|}{ Oxygen Capacity } & \multicolumn{2}{c|}{ Haldane's Haemoglobinometer } \\
\hline & $\begin{array}{c}\text { Van Slyke and } \\
\text { Stadie (1921) }\end{array}$ & $\begin{array}{c}\text { Haldane } \\
(1900)^{28}\end{array}$ & $\mathrm{Hb} \%$ & $=0_{2}$ capacity \\
\hline $\begin{array}{l}\mathbf{O}_{2} \text { capacity } \\
=\mathrm{Hb} . \%\end{array}$ & 20.67 & 20.20 & 112.25 & \\
\hline
\end{tabular}

Price-Jones also tested the twenty subjects with his Haldane haemoglobinometer, with the results shown in Table $3 .^{32}$ These results agreed well with the previous American figures of Haden, Osgood, and Wintrobe and Miller ${ }^{33}$ (see Table 2), but it will be seen that for oxygen capacity they exceeded not only the figures determined directly by Haldane's method, but also those determined by van Slyke and Stadie's method, and so threw doubt upon the reliability of Price-Jones' standard tube.

The standard tube actually used by Price-Jones was one which he had used for thirty years, and which he claimed had "remained unaltered" for this period. ${ }^{34}$ As it was originally calibrated by the oxygen capacity method of Haldane, the readings obtained by Price-Jones in 1931 seem to suggest that his standard may have faded with the passage of time so that the 100 per cent was actually equivalent to 18 per cent oxygen capacity instead of 18.5 per cent. If this were the case, then the difference between the normal levels of British subjects observed by Haldane and Smith during 1900-01, and those observed by Price-Jones in 1931 (see Table 2), as well as those between the haemoglobin levels and oxygen capacities in Price-Jones' American series are also partly explained.

29 D. D. van Slyke and W. C. Stadie, 'The determination of the gases of the blood', J. biol. Chem., 1921, 49: 1-42. This method was based upon that first described three years earlier by $D$. $D$. van Slyke, 'Gasometric determination of the oxygen and hemoglobin of blood', ibid., 1918, 33: 127-132.

${ }_{20}$ Van Slyke and Stadie, op. cit., note 29 above, pp. 21-22.

${ }^{31}$ Price-Jones, op. cit., note 16 above.

22 Ibid.

s3 Haden, op. cit., note 24 above; Osgood, op. cit., note 20 above; Wintrobe and Miller, op. cit., note 22 above.

a4 Price-Jones, op. cit., note 16 above, p. 779. 


\section{Some problems in the history of haemoglobinometry (1878-1931)}

Direct evidence for the permanence of Price-Jones' standard is limited to a passing note in a Medical Research Council investigation into haemoglobin levels in Britain in $1943,{ }^{35}$ which suggested that the standard used by Price-Jones in 1931 was still reasonably accurate twelve years later. In fact there is little evidence anywhere of the extent and direction of colour changes occurring in Haldane standards after prolonged storage and use, although it was recognized that changes were liable to take place, and it was generally recommended that the standard tubes be "kept in a dark place". In 1943 the Medical Research Council Committee on Haemoglobin Surveys reported that: "The difficulties of preparing and maintaining accurate colour standards in the past have often led to significant discrepancies between the values of the colour tubes used by earlier investigators. Further, colour tubes have sometimes slowly faded . . . during the period of their use." ${ }^{36}$ It seems probable, therefore, that some fading of standards was liable to occur over extended periods of time. It is a pity that Price-Jones did not use a new colour standard tube for his 1931 series of tests, for this might have produced less puzzling results.

\section{DISCUSSION}

Two separate distinctions were apparently being made by Price-Jones in 1931, using his thirty-year-old carboxyhaemoglobin standard tube: (1) an increase in the "normal" haemoglobin level in Britain between 1900 and 1931, and (2) a higher "normal" level in America in 1931 than in Britain at the same time. The relevant figures are summarized in Table 4.

TABLE 4

Haemoglobin concentrations based upon Haldane's standard. Differences in "normal" levels, related to time and place.

\begin{tabular}{|l|c|c|cc|}
\hline & & & \multicolumn{2}{|c|}{ Haemoglobin } \\
\cline { 3 - 4 } Observers & Date & Country & per cent & $=\mathrm{g} / \mathrm{dl}$ \\
\hline Haldane and Smith & $1900-01$ & Ireland & 100 & 13.8 \\
Price-Jones & 1931 & England & 105.4 & 14.5 \\
Price-Jones & 1931 & U.S.A. & 112.25 & 15.5 \\
& & & & \\
\hline
\end{tabular}

(1) The reality of the distinction between Price-Jones' figures for British subjects in $1900-01$ and 1931 is arguable. There would seem to be at least four factors extraneous to the thirty-year interval in time, any of which may have been partially-or even entirely-responsible for the observed discrepancy.

(a) The original work by Haldane and Smith in 1900 and Haldane in $1901^{37}$ had ${ }^{25}$ Medical Research Council, Special Report Series No. 252, Haemoglobin levels in Great Britain in 1943, London, H.M.S.O., 1945, p. 36, table XV.

"o Ibid., p. 121.

${ }^{37}$ Haldane and Smith, op. cit., note 12 above; Haldane, op. cit., note 7 above. 


\section{A. D. Farr}

established a normal value on the basis of two series of tests upon fourteen and twelve men respectively. Further, these twenty-six men were all of a similar social class and, although described as "normal" and "perfectly healthy", could only be so in the context of their own social stratum. Haldane and Smith had utilized "students or practitioners of medicine working in the laboratory,"38 and this group was not likely to represent the best-nourished section of the population, laboratory work being almost the most poorly rewarded area of medicine at that time, and the poverty of students being proverbial. Statistically, a series of twenty-six was little enough upon which to establish normal levels for a whole population, and the relative homogeneity of those twenty-six subjects meant that whatever figure was arrived at was unlikely to be typical of the whole community.

(b) The subjects examined in 1900-01 were all from Belfast, and those of Haldane had an average age of thirty-one. ${ }^{39}$ The later (much larger) group tested by PriceJones in 1931, while of a comparable social position, had an average age of twentyseven $^{40}$ and all were resident in London. Both the average age and the geographical location were variables which could have affected the mean values obtained. While the effect of a four-year younger mean age in the later series is unlikely to have had any significant effect, the different standards of living to be expected between Northern Ireland at the turn of the century and central London three decades later were sufficient to make the two groups simply not comparable.

(c) Observer error has always been a problem with visual colour matching techniques. In 1945 Macfarlane reported that individual observers showed a range of personal variation averaging 4.8 per cent on the Haldane scale, with a range of 2.0 to 13.9 per cent. ${ }^{41}$ While Haldane and Smith, working in the same laboratory, may well have achieved closely comparable results, the difference between their figures and Price-Jones' was 5.4 per cent (see Table 4)-sufficiently close to Macfarlane's observation of personal variation to suggest that this alone could have accounted for Price-Jones' reported higher "normal" haemoglobin levels.

(d) Did Price-Jones' standard tube fade over a period of thirty years, sufficiently to account for his suggestion that mean normal haemoglobin levels had risen by 5.4 per cent during that period? It certainly seems likely that this type of standard was liable to fade over extended periods of time, and the evidence of Price-Jones' American series in 1931 strongly suggests that this had occurred with his own colour tube. Whether this extended to a difference of 5.4 per cent cannot be known.

In summary, it seems probable that the difference between the observed "normal" levels, in Britain, of 1900-01 and 1931 was due to a combination of inadequate size and selection of subjects in the first surveys; fading of Price-Jones' colour standard over a period of thirty years; and-perhaps most important-observer error inherent in the technique of the Haldane/Gowers method.

(2) The higher "normal" level reported in 1931 by Price-Jones in America, as compared

88 Haldane and Smith, op. cit., note 12 above, p. 339.

29 Haldane, op. cit., note 7 above, p. 502. Range $=19-62$.

${ }^{10}$ Price-Jones, op. cit., note 16 above, p. 780. Range $=20-51$.

“ R. G. Macfarlane, in M.R.C. report, op. cit., note 35 above, p. 83. 


\section{Some problems in the history of haemoglobinometry (1878-1931)}

with Britain, almost certainly represents a more real distinction than that alleged within Britain between 1900 and 1931. Price-Jones' figures for Americans were consistent with those of several other observers (see Table 2), while his figures for Britain were confirmed in a series of ninety medical students tested four years later, ${ }^{42}$ and were actually higher than those reported for fifty medical students ${ }^{43}$ and forty-two professional and artisan workers ${ }^{44}$ a year after that. Thus, a genuine difference between British and American "normal" haemoglobin levels appears to have existed in the 1930s.

One may suspect that general living standards, and especially dietary levels, were possibly higher in America for the middle classes than they were in Britain at that time, and some evidence exists to suggest that diet may indeed have played a significant part in the differences observed. One modern source concisely summarizes the position thus: "The main factor limiting the production of sufficient haemoglobin to satisfy the needs of erythropoiesis is the supply of iron." 45 While it has been shown that men can be in good health, without anaemia, ${ }^{46}$ on a daily intake of $6 \mathrm{mg}$ of iron-or possibly even less ${ }^{47}$-it has usually been considered that $12 \mathrm{mg}$ is the recommended minimum daily intake. ${ }^{48}$

During the period 1926 to 1936 a number of studies were performed to determine iron requirements and, although most of these were concerned specifically with low-income groups, ${ }^{49}$ or with iron balance studies, some reported the daily iron intake in freely chosen diets amongst a broadly representative cross-section of society. The results of four of these surveys-two in Britain and two in America-are summarized in Table 5 (p.160).

From this data it is clear that, while in both countries the average intake of iron in the early 1930s was above the minimum necessary for "good health", the daily intake in America was $1.45 \mathrm{mg}$ (i.e. nearly $9 \frac{1}{2}$ per cent of the intake) greater than in Britain. It would seem probable, therefore, that diet played a much larger part in explaining the higher "normal" levels of haemoglobin observed in America than Price-Jones was prepared to concede. Certainly, this factor would more convincingly account for the difference than would the carbon monoxide poisoning arising from a greater use of motor cars, which Price-Jones actually proposed.

\section{SUBSEQUENT DEVELOPMENTS}

The Haldane/Gowers method of haemoglobin estimation was studied in depth in 1943 by a Medical Research Council Committee on haemoglobin surveys and its

48 C. Price-Jones, J. M. Vaughan and H. M. Goddard, 'Haematological standards of healthy persons', J. Path. Bact., 1935, 40: 503-519.

\&s M. McGeorge, 'Haematological variations in fifty normal adult males', ibid., 1936, 42: 67-72.

a E. M. Widdowson and R. A. McCance, 'Iron in human nutrition', J. Hyg., Camb., 1936, 36: 13-23.

45 G. H. Bell, J. N. Davidson and H. Scarborough, Textbook of physiology and biochemistry, 7th ed., Edinburgh, Livingstone, 1968, p. 483.

46 I.e., with haemoglobin levels greater than $11.7 \mathrm{~g} / \mathrm{dl}$.

47 L. S. P. Davidson, H. W. Fullerton, J. W. Howie, J. M. Croll, J. B. Orr, and W. Godden, 'Observations on nutrition in relation to anaemia', Br. med. J., 1933, i: 685-690.

${ }^{48}$ E.g., Report, Committee on Nutrition, London, British Medical Association, 1950.

49 E.g., Davidson et al., op. cit., note 47 above. 


\section{A. D. Farr}

TABLE 5

Average daily intake of iron in Britain and America, 1926-1936.

\begin{tabular}{|c|c|c|c|c|c|c|}
\hline Date & Observers & Place & Subjects & $\begin{array}{c}\text { No. } \\
\text { Observed }\end{array}$ & \multicolumn{2}{|c|}{$\begin{array}{l}\text { Average daily intake } \\
\text { Fe, in mg. } \\
\text { U.K. U.S.A. }\end{array}$} \\
\hline 1929 & Hawleyso & $\begin{array}{l}\text { U.S.A. } \\
\text { (36 states) }\end{array}$ & $\begin{array}{l}\text { College } \\
\text { students }\end{array}$ & $\begin{array}{l}58 \\
\text { institutions }\end{array}$ & \multirow{2}{*}{\multicolumn{2}{|c|}{16}} \\
\hline 1930 & Orr and Clark ${ }^{61}$ & $\begin{array}{l}\text { Scotland } \\
\text { (7 towns } \\
\text { and cities) }\end{array}$ & $\begin{array}{l}\text { Working- } \\
\text { class } \\
\text { families }\end{array}$ & $\begin{array}{l}607 \\
\text { families }\end{array}$ & & \\
\hline 1933 & Sherman ${ }^{62}$ & U.S.A. & $\begin{array}{l}\text { "Typical" } \\
\text { families }\end{array}$ & $\begin{array}{l}224 \\
\text { families }\end{array}$ & \multirow{2}{*}{\multicolumn{2}{|c|}{18}} \\
\hline 1936 & $\begin{array}{l}\text { Widdowson and } \\
\text { McCance"t }\end{array}$ & London & $\begin{array}{l}\text { Middle- and } \\
\text { working- } \\
\text { class men }\end{array}$ & 63 men & & \\
\hline & & & & MEAN: & 15.55 & 17 \\
\hline
\end{tabular}

report ${ }^{53}$ led to a much clearer appreciation of the problems of haemoglobinometry than had existed until that time. The introduction of British standards for haemoglobin pipettes ${ }^{54}$ and colour standard tubes, ${ }^{55}$ together with the introduction of colour matching by "Photoelectric Colorimeter", ${ }^{56}$ led to improvements in accuracy until new methods, both of converting haemoglobin compounds into a measurable form, and of measuring their concentration, superseded the technique which had made haemoglobin estimation clinically useful, and almost scientifically respectable.

With the single modification of Haldane in 1901, Gowers' technique remained in use otherwise unaltered for very nearly a century-surely evidence of the soundness of his basic concept.

${ }^{50}$ E. Hawley, Nutritive value and cost of food served to college students, Circular No. 89, U.S. Department of Agriculture, 1929. These figures were collected in 1926 from thirty-five institutions studied by the U.S. Bureau of Home Economics, and twenty-three studies made by L. W. Hunt, at the State College of Washington, in different Halls of Residence. The figures reported were in terms of "adult-male units".

51 J. B. Orr and M. L. Clark, 'A dietary survey of 607 families in 7 cities and towns in Scotland', Lancet, 1930, ii: 594-598.

${ }^{52}$ H. C. Sherman, Food products, 3rd ed., New York, Macmillan, 1933.

${ }^{58}$ M.R.C. report, op. cit., note 35 above.

«4 B.S. 797 (1938).

s5 B.S. 1079 (1942)

58 E. J. King and M. Geiser, 'Haldane haemoglobin determination with the photoelectric colorimeter', Biochem. J., 1950, 46. In 'Proceedings of the Biochemical Society'. pp. xxv-xxvi. 